\title{
Stock Market Reactions to Dividend Announcements: Empirical Evidence From the Singapore Stock Market
}

\author{
Shailender Singh (Corresponding author) \\ Associate Professor, Department of International Finance \\ I-Shou University, Taiwan \\ Tel: 886-90-936-1766_E-mail: reshu111us@yahoo.com \\ Pooja Jain \\ Assistant Professor, Shri Guru Ram Rai University, India \\ E-mail:dr.pujajain@gmail.com
}

Voon Chen Wei

MDIS Business School, Singapore

Received: April 4, 2018

Accepted: April 20, 2018

Published: May 27, 2018

doi:10.5296/ijafr.v8i2.12949

URL: https://doi.org/10.5296/ijafr.v8i2.12949

\begin{abstract}
The present study investigates the 50 randomly selected companies from Singapore Stock Exchange to assess the impact of the dividend initiation announcement and omission announcement on the share prices of the companies under study. The study has analyzed the impact of dividend initiations announcement on the size of firms by dividing the firms into small and big categories. Further, the relationship between changes in dividend and company's future earnings is also analyzed. The study finds that the dividend initiation announcement's impact on the share prices of Singapore companies is trivial and uncertain.
\end{abstract}

Keywords: Dividend announcements, Dividend initiation, Dividend omission, Future earnings, Market's reaction, Singapore Stock Exchange 


\section{Introduction}

It is widely accepted in financial theory that a company's dividend policy has a non-trivial impact on the wealth of its shareholders. Academics have been conducting research on dividends for many decades; however, the conclusions of this research effort can be summarized by the views of Fisher Black when he stated that "the harder we look at the dividend picture, the more it seems like a puzzle, with pieces that just don't fit together (Black, 1976, p. 5). Academics have formulated various theories and empirical explanations as to how and why a firm pays a dividend, even where dividends are taxed more heavily than capital gains. Many of these studies have been conducted in countries with developed stock markets such as US (Lintner, 1956; Pettit, 1972), UK (Lonie et al., 1996; Dhanani, 2005) and Ireland (McCluskey et al., 2006).

This study analyses the impact of dividend announcements on the share prices of firms listed on the Singapore Stock Exchange. Academics from developed stock markets have put forward various theories regarding the extent to which dividends affect the value of the firm. In addressing this question, opinions can generally be divided into three groups. First, a number of financial researchers claim that dividend policy has no impact on firm value, leading to the hypothesis that dividends are irrelevant (Miller and Modigliani, 1961; Black and Scholes, 1974; Miller and Scholes, 1982; Uddin, 2003; Kaleem and Salahuddin, 2006). The dividend irrelevance hypothesis was advanced by Miller and Modigliani (MM) in their seminal study in 1961. This hypothesis argues that investors are unconcerned as to whether they receive the firm's earning in the form of dividend or capital gain. Therefore, a change in dividend does not affect the firm's value. Any increase in dividend is offset by a capital loss as firms raise the cash for the changed payout by an issue of shares. The dividend irrelevancy theory proposes, therefore, that the real value of a firm is influenced only by its investment opportunities and profitability and not by its dividend policy.

Second, another group of researchers argues that a rise in dividend payout increases the value of a company because dividend conveys information to investors about the future prospects of the firm (Pettit, 1972; Lonie et al., 1996; McCluskey et al., 2006). The 'information content' hypothesis suggests that in a world of information asymmetry, where managers know more than outsiders about the current operations and future plans of their company, a change in dividend may signal the beliefs of these insiders and affect the value of a firm (Bhattacharya, 1979; Bhattacharya, 1980). The information content hypothesis assumes that an increase in dividend is "good news" while a dividend cut is a "bad signal" about the future earnings of the company. This assumption draws on the seminal work of Lintner (1956) who documented that firms tended to increase their dividends only when they were reasonably certain that the new higher payout rate could be maintained into the future. This implies that an increase in dividend is a favourable signal about higher future earnings which in turn affects share prices. A number of behavioural studies have supported the signaling notion (Baker et al., 1985; Baker and Powell, 1999; Brav et al., 2005; McCluskey et al., 2007). In addition, many studies have provided quantitative empirical evidence to support the signaling hypothesis that dividend announcements affect the share prices of a firm (Pettit, 1972; Lonie et al., 1996; McCluskey et al., 2006). 


\section{Ml Macrothink}

International Journal of Accounting and Financial Reporting

ISSN 2162-3082

2018, Vol. 8, No. 2

Given the large body of evidence on efficiency in developing markets, there is a need for "triangulation" in the research by providing further evidence from developed markets. This study extends the evidence on the efficiency of emerging stock markets using data from the Singapore Stock Exchange.

\section{Literature Review}

According to L'Heureux (2000) who conducted a study on the Canadian market, she tested the market reaction to dividend omission and resumption announcements. Significant negative abnormal returns are observed for a three days announcement period either omission or initiation. However, there is no significant shift of beta is found. She also found that the firms' size or quantum of dividend changes is not affecting the abnormal returns.

L'Heureux (2000) also found that dividend omission announcements generate negative abnormal returns and changes in trading value. By using the method of cumulative abnormal returns model (CAR) in the report, it was found that corporations which omitting their dividend payout and somehow resume their dividend payment will generate negative CAR. The finding is similar to those corporations which are omitting their dividend payout but never resume it.

Even though the study is done on the Canadian market, it is compared with American market which is found that the findings among the two studies are very consistent. L'Heureux (2000) states that when a corporation stops the dividend payment, investors will perceive this as a negative signal. The investors cannot predict when the corporations will resume the dividend payout too. Besides that, even if the corporation resumes the dividend payment, it does not convey any new information to the investors.

In the study by Sun (2005), she examines the relation among dividend changes, earnings persistence, and the market's response to earning news. The study focuses on the changes and relationship between the past earnings and dividend policy. A change in dividend policy such as initiation or omission, may affect an investor's assessment and judgement about the firm's past earnings information. This also further explains the positive market reaction following a positive dividend announcement which has frequently observed by researchers. Vice versa, a negative market reaction will prompt surrounding dividend decreases.

Healy and Palepu (1987) did a study on the impact of dividend initiation or omission impacts to a firm's decisions. They found that firms that initiate (omit) dividend payments tend to have positive (negative) earning changes at the occasion before and after the changes of dividend policy. Then the following earnings changes are positively correlated to the dividend announcement. Also, the stock price changes at the announcement of subsequent earnings are smaller than usual.

Healy et al (1987) use a sample that comprises 131 firms that pay dividends for the first time or resume payments after a hiatus of at least ten years and 172 firms that omit dividend payments for the first time or after continuously paying for at least ten years. There are three main issues to be tested by using those samples. First of all, the changes in a firm's earning performance for five years before and after a dividend initiation or omission are documented. 


\section{MInstitute ${ }^{\text {Macrothink }}$}

International Journal of Accounting and Financial Reporting

ISSN 2162-3082

2018, Vol. 8, No. 2

Next, they examine whether subsequent earning changes are related to the information released at the dividend announcement, as measured by the announcement return. Finally, they analyzed the market reaction to earning announcements subsequent to the dividend policy change to assess whether the market anticipates these earnings from the dividend announcement.

Another study was done by Ibrahim (2002), which is a re-examination of the market's reaction to quarterly dividend change announcements also testing on how the dividend announcement affect the changing of a firm value, or its stock price. According to the dividend information content hypothesis, dividend changes trigger stock returns because they reflect changes in management's assessment of a firm's future profitability. Ibrahim (2002) has classified the dividend change announcement into favourable and unfavourable depending on their direction. Then, the results reflected how the market reactions are for these four conditions: first, dividend increases that convey favourable information regarding the firm future profitability; second, dividend increases that convey unfavourable information regarding the firm future profitability; third, dividend decreases that convey favourable information regarding the firm future profitability; fourth, dividend decreases that convey unfavourable information regarding the firm future profitability.

Asquith and Mullins (1983) were the first to document that more than $30 \%$ of their sample experienced a negative market reaction to a dividend initiation. The authors attribute this adverse reaction to the failure of the naive expectation model (i.e. the change in dividends) rather than to a real adverse reaction to the dividend initiation. In their study, they investigate the impact of dividends on stockholders' wealth by analyzing 168 firms that either pay the first dividend in their corporate history or initiate dividends after a ten years hiatus. The results show that for the particular sample of the firms, initiating dividends increases the shareholders' wealth. Dividend policy has several attractive aspects as an information transmission mechanism. Dividends can be used as a simple, comprehensive signal of management interpretation of the firm's recent performance and its future prospects.

Unlike most other announcements, dividend announcements must be backed with hard cold cash. In order to confirm the announcement, the firm has to either generate this cash or convince the capital markets to supply it. Apart from the credibility of the cash signals, dividend announcements are also highly visible compared with other types of announcements. These advantages are also shared by stock repurchases. Stock repurchases may convey information which can stimulate the market and thus affect the firm's value. However, the timing of the stock repurchases is irregular and at the discretion of the management. Dividends announcements are fixed and periodic, which is more acceptable to investors. In conclusion, Asquith et al (1983) found that initiating a dividend policy does matter and that the market reaction is strong and positive.

There were a number of motivations for the decision to study dividend decisions in Singapore. First, a review of the literature showed that the information content of dividends had been comprehensively studied in developed stock markets around the world such as the US, the UK, Australia and Ireland. However, relatively little work had been undertaken in Asian 
markets; this was especially true for Singapore. Therefore, it was felt that a comprehensive investigation of the impact of dividend announcements on the share prices of Singapore-listed firms would make an important contribution to knowledge.

\section{Research Questions}

3.1 Research Question 1: Does omission of dividend create a negative impact on a company's share price?

As suggested by L'Heureux (2000), dividend omission announcement creates a negative impact on the abnormal return of the company and changes its trading value. Consistent with L'Heureux findings, Sun (2005) and Healy and Palepu (1987) also conducted an investigation on the issue, and they concluded that omission of the dividend will cause the share price of a company to decrease. The information carried along with the dividend announcement will lead investors to deem that it has negative future forecast, and thus drive the share price of that company to go down.

However, in a study done by Ibrahim (2002) found that omission of the dividend will create a positive impact on the company's share price, or the firm's value. Some of the few factors that may cause this situation to occur are that investors would perceive that the firm has another plan in the future, which might require the capital. Even though the company did not payout any dividend, it may have a good prospect of future investment, which is a value creation for its investors too. In view of this, even though there is no immediate bonus to be received, the future prospect of the company is secured, and the company share price may increase. Thus, the positive impact on the share price is expected.

Besides the studies that show the impact on the share price due to the omission of dividend, there are some studies shows that there is neither positive nor negative impact. Miller and Modigliani (1961) show no relationship between dividend announcement and share price. While consistent with Miller et al., Watts (1973) also stated that dividend announcement does not have any impact on the company's share price. Inspired by the above few studies, this research work emphasizes to test the impact of the omission of dividend to share price of the company for Singapore economy.

3.2 Research Question 2: Does initiation of dividend create a positive impact on a company's share price?

This research question is inspired by the studies done by a few researchers. There are basically a few different schools, such as one school supports initiation of dividend creates a positive impact on the share price. While another school of researchers documents the negative impact on share price when there is initiation of dividend. Lastly, there is another group of researchers who comment that there will be no significant impact on share price whenever there is initiation of dividend.

In order to segregate the studies to those different school of thought, the below studies has been group accordingly. First of all is Walsh (2001), who found that the firm value increases when there is initiation of dividend. The increment of firm value will be translated into the 
share price of the company. Next, Sun (2005) reported that initiation of dividend creates a positive impact on share price, which is consistent with the finding of Walsh. Lastly, Healy and Palepu (1987) who investigated regarding the issue and found that initiation of the dividend will have a positive impact on share prices.

Then, some researchers found the result quite contrast with the above-mentioned studies. Ibrahim (2002) shows that initiation of dividends will create a negative impact on share price of the company, as well as Asquith and Mullins (1983).

Some other studies which are totally different from the previous two groups of researchers are Miller and Modigliani (1961) and Watts (1973). Their studies show that there is no relationship between dividend announcement and share price. Their studies cover dividend initiation announcement and dividend omission announcement impact on the share prices. Both types of the announcement show little evidence to support the statement as mentioned in Research Question 2.Further, from those studies, an analysis is conducted in this research work, to add more purified findings in the existing literature.

3.3 Research Question 3: Does dividend initiation announcement only create an impact on share prices of smaller firms?

Research Question 3 is different from Research Question 1 and 2 because it is not to test the impact of dividend announcement on the share price. But rather, it is to test on the dividend announcement relationship with the size of the company. To elaborate, it is to determine whether the reaction of a small company after a dividend announcement is the same as the reaction of a big company after a dividend announcement.

There are a few studies which did the investigation regarding this topic. First of all, Pettit (1972) studied and found that dividend announcement will affect the share price of the company. This is very clear that dividend announcement conveys information which can affect how investors perceive regarding a certain company according to Pettit. When studied further, Gurgul, Majdosz, and Mestel (2006) suggest that dividend increase (decrease) resulted in share price increment (decrement). McCluskey, Burton, Power, and Sinclair (2006) documented statistically significant market reaction following dividend announcement.

The next stage of the study is that, is the reaction of the share price is different when the size of the companies differ? According to L'Heureux (2000), the size of the corporation will not be affected by the dividend announcement. Very much different from the study of L'Heureux, Walsh (2001) shows the weak relation between the announcement and firm value of smaller companies.Through all the different outcomes from different researchers, this has prompted the Research Question 3. Thus, the objective of this research question is to find out is the dividend initiation announcement affects only the share price of smaller firms?

3.4 Research Question 4: Do changes in dividend affect the changes in companies' future earnings?

In this research question, the objective is to find out the relationship between changes in dividend and companies' future earnings. There are couple of studies which were carried out 


\section{Macrothink}

International Journal of Accounting and Financial Reporting

ISSN 2162-3082

2018, Vol. 8, No. 2

to study the similar subject, however, their findings are different. First of all, Ibrahim (2002) shows that there is a positive relationship between dividend changes and company's future profitability. This finding is further enhanced by a research done by Watts (1973). Watts found that there is a positive relationship between dividend changes and future earnings of companies. These two researchers share the same conclusion and support that changes of the dividend will affect a company's future earnings. The impact is a positive impact.

While in a study conveyed by Benartzi, Michaely, Thaler (1997), they are unable to find any evidence to support the view that changes in dividend affect future earning changes. DeAngelo, DeAngelo, and Skinner (1995) also find virtually no support for the notion that dividend decisions help identify firms with superior future earnings. By looking at these two studies, the conclusion is totally different from the previous two findings.

The dividend announcement may affect the future earnings of companies is mainly because there is information which is conveyed together with the announcement, and affect investors' perceptions. Yan (2000) suggested that no all dividend changes contain new information about future earnings. Indirectly, Yan also concluded that not all dividend announcements will affect the companies' future earnings. In view of the various kinds of answers produced by all the previous researchers, this has prompted this research question. The objective is to obtain evidence to support previous research findings.

\section{Research Hypotheses}

The hypotheses of the study are stated in null form as follows:

$\mathbf{H}_{10}$ : Dividend omission will not create a negative impact on the companies' share price

$\mathbf{H}_{\mathbf{2 0}}$ : Dividend initiation will not create a positive impact on the companies' share price

$\mathbf{H}_{30}$ : Dividend initiation announcement not only create an impact on share prices of smaller firms

$\mathbf{H}_{\mathbf{4 0}}$ : Changes in dividend will not affect the changes in companies' future earnings

\section{Research Objective}

The present study investigates the impact of dividend announcements on share prices in the emerging stock market of Singapore. The following are the three main objectives:

1.) To study the effect of dividend omissions on share prices of the companies.

2.) To ascertain whether any signal relating to dividend news interacts with future earnings announcements.

3.) To analyze the impact of dividend initiation announcement on share prices of big and small companies.

\section{Data and Methodology}

The data sample is drawn from all dividend announcements made by 50 randomly selected companies from the Singapore Stock Exchange (SGX) that announced dividend increases or 


\section{Mll Macrothink}

International Journal of Accounting and Financial Reporting

ISSN 2162-3082

2018, Vol. 8, No. 2

decreases from 2009 to 2013. These companies have different business nature, inclusive of large and small firms. Firms that announce a special dividend in the announcement year are excluded from this study. This requirement is to ensure that all firms in the sample had the dividend and daily stock price data. The stock price data and the dividend data are available from Datastream, Thompson Financial Service.

The trend of how a company made the dividend announcement is observed. For example, Singapore Airlines Limited (SIA) made their dividend announcement twice yearly. For every year, in the month of August and November, SIA would initiate its dividend and made a public announcement. From the data collected, it was observed that from the year 2009 to 2012, SIA initiated the dividends consistently. However, in the year 2013, there is only one dividend announcement made. In the month of August, from the past record, in November, there should be another announcement made. Since there is no dividend announcement recorded for November 2013, this will be recorded as dividend omission. All the 50 companies chosen have been analyzed through this procedure, and the frequency of the omission is recorded and tabulated.

The data which have been analyzed in this study is the frequency of omission done by the companies and the share prices of the companies. The share prices of the companies are collected 20 days before and after the omission. The average share prices are compared before and after the omission date. From the differences, it is determined that the share prices are increased or decreased. In order to analyze for all the companies with the omission, the data is analyzed statistically. All the differences are tabulated and then tested by using Z-Test.

The sample size is determined by the total number of omissions that are announced from the year 2009 to 2013. After the sample size is obtained, the mean of the samples is calculated. This is the mean of the share prices 20 days before and 20 days after the dividend omission announcements. By taking the mean value of the 20 days after the dividend omission announcements to deduct with the mean value of the 20 days before the dividend omission announcements, the share price difference is calculated. If the value is positive, it means the share price has increased after the omission announcements and vice versa. The mean of the sampling distribution is the value that is to be compared with. Besides taking the share price differences before and after the dividend announcement date as the primary input, the percentage change is also evaluated. The percentage is screened through in order to take those more reliable data into consideration. For an instance, by looking at a share price difference of $\$ 0.50$ may not have any impact. However, when this figure is converted into a percentage, it may become $300 \%$ change, which is quite a substantial figure. Thus, the screening process is looking at the overall realistic numbers and sieved out those unwanted numbers which may affect the result. 


\section{Results and Findings}

Table 1. Companies and frequency of dividend omission

\begin{tabular}{clc}
\hline No. & \multicolumn{1}{c}{ Company } & Frequency of Dividend Omission \\
\hline $\mathbf{1}$ & Bukit Sembawang Estates Limited & 1 \\
\hline $\mathbf{2}$ & Creative Technology Limited & 1 \\
\hline $\mathbf{3}$ & Ezra Holdings Limited & 4 \\
\hline $\mathbf{4}$ & Golden Agri Resources Limited & 2 \\
\hline $\mathbf{5}$ & Ho Bee Investment Limited & 1 \\
\hline $\mathbf{6}$ & Keppel Corporation Limited & 1 \\
\hline $\mathbf{7}$ & Midas Holdings Limited & 1 \\
\hline $\mathbf{8}$ & Neptune Oriental Lines Limited & 1 \\
\hline $\mathbf{9}$ & Parkway Holdings Limited & 4 \\
\hline $\mathbf{1 0}$ & Raffles Education Corporation Limited & 3 \\
\hline $\mathbf{1 1}$ & Singapore Airlines Limited & 1 \\
\hline $\mathbf{1 2}$ & Singapore Post Limited & 1 \\
\hline $\mathbf{1 3}$ & Singapore Telecommunications Limited & 1 \\
\hline $\mathbf{1 4}$ & Starhub Limited & 2 \\
\hline $\mathbf{1 5}$ & Swissco International Limited & 1 \\
\hline $\mathbf{1 6}$ & Wilmar International Limited & 2 \\
\hline $\mathbf{1 7}$ & Yeo Hiap Seng Limited & 4 \\
\hline
\end{tabular}

Source: www.sgx.com.

Table 1 reveals that there are total 17 companies out of 50, which have the omission of dividend throughout the year 2005 - 2009. Every company has a different amount of omission announcement, and the total omissions recorded is 31 times.

Table 2. Z-test result for share price differences (omission)

\begin{tabular}{cc}
\hline Description & Figure \\
\hline Sample size & 31 \\
\hline Mean & 0.073532097 \\
\hline Standard Deviation & 0.167377469 \\
\hline Level of Significance & 0.05 \\
\hline Z-value & 2.446024483 \\
\hline
\end{tabular}

Source: Data Analysis

From Table 2, the Z-value is calculated by comparing the differences of share prices. The alternative hypothesis is determined so that to test that omission of the dividend would create a negative impact on share prices. Thus, by analyzing the differences in the share prices, as suggested by McCluskey et al (2006), share prices 20 days before and 20 days after the omission are compared. If the share prices decrease after the omission, then the alternative hypothesis can be proven to true. From this logic, the hypothesis as below is developed: 


\section{Macrothink}

$\mathrm{H}_{0}: \mu \geq 0$

$\mathrm{H}_{\mathrm{A}}: \mu<0$

Where, $\mu=$ the differences between the share prices

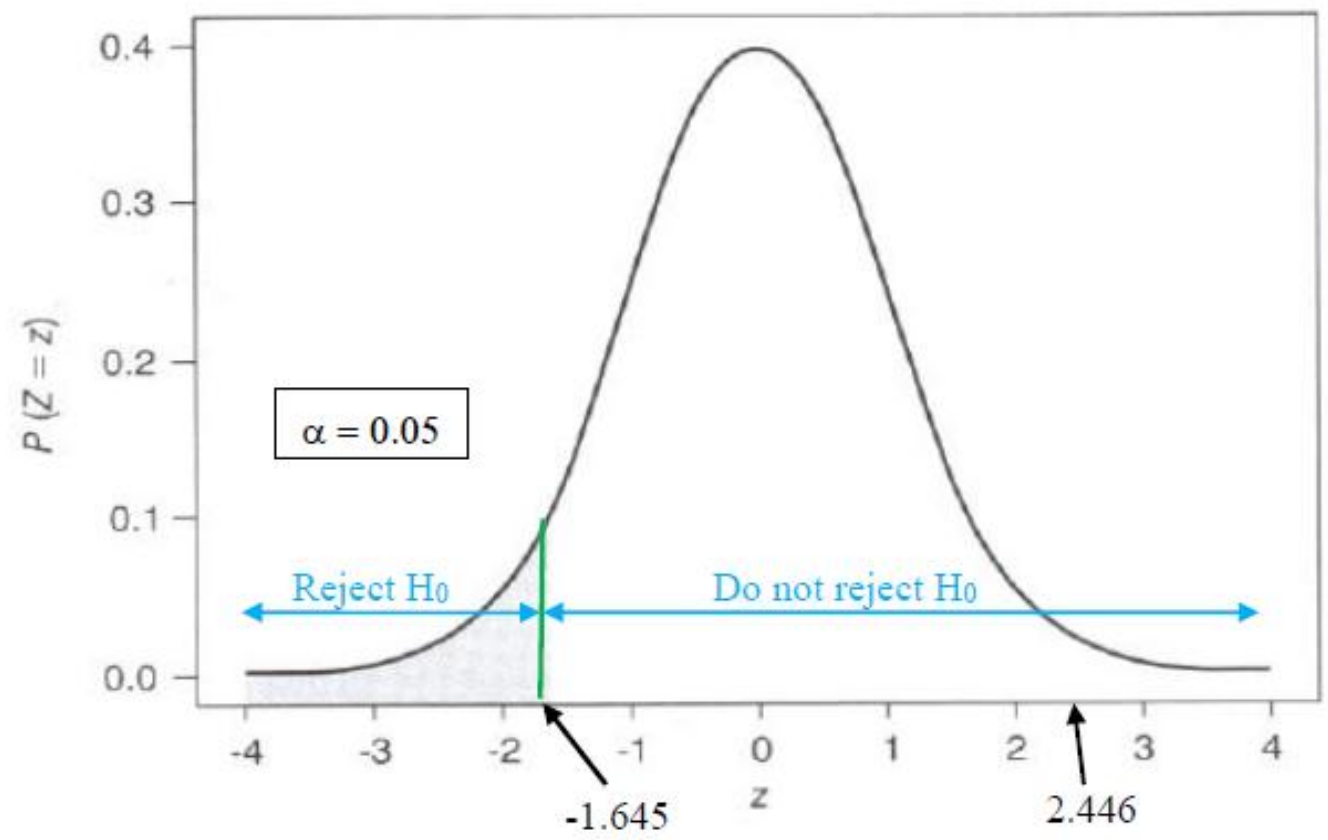

Figure 1. Rejection region for a one-tail test of a 'greater than or equal' null hypothesis at the 5 percent level of significance

In this test, the level of significance is 5 percent, thus, if the $\mathrm{Z}$-value is smaller than -1.645 , it would reject the null hypothesis $\mathrm{H}_{10}$. From Table 2, we can see that the $\mathrm{Z}$-value calculated is 2.446, the value falls into the right-hand side of the chart as in Figure 1, hence the null hypothesis is not rejected. There is enough evidence to support the claim that dividend omission will not create a negative impact on companies' share prices at 5 percent level of significance.

Table 3. Z-test result for differences in percentage (omission)

\begin{tabular}{lc}
\hline Description & Figure \\
\hline Sample size & 31 \\
\hline Mean & $4.360 \%$ \\
\hline Standard Deviation & 0.083321054 \\
\hline Level of Significance & 0.05 \\
\hline Z-value & 2.913516571 \\
\hline
\end{tabular}

Source: Data Analysis 


\section{Macrothink}

International Journal of Accounting and Financial Reporting

ISSN 2162-3082

The result shown in Table 3 is similar to the set of data in Table 2. The only difference here is that the differences in share prices are input as a percentage. By converting the share price differences into a percentage, the research hypothesis from another point of view can be examined. For this calculation, the hypothesis test remains the same, ie. the alternative hypothesis is "dividend omission will create a negative impact on share prices". Thus, there will have enough evidence to support the null hypothesis if the percentage differences are equal or more than zero.

$\mathrm{H}_{0}: \mu \geq 0$

$\mathrm{H}_{\mathrm{A}}: \mu<0$

Where the differences between the share prices in percentage.

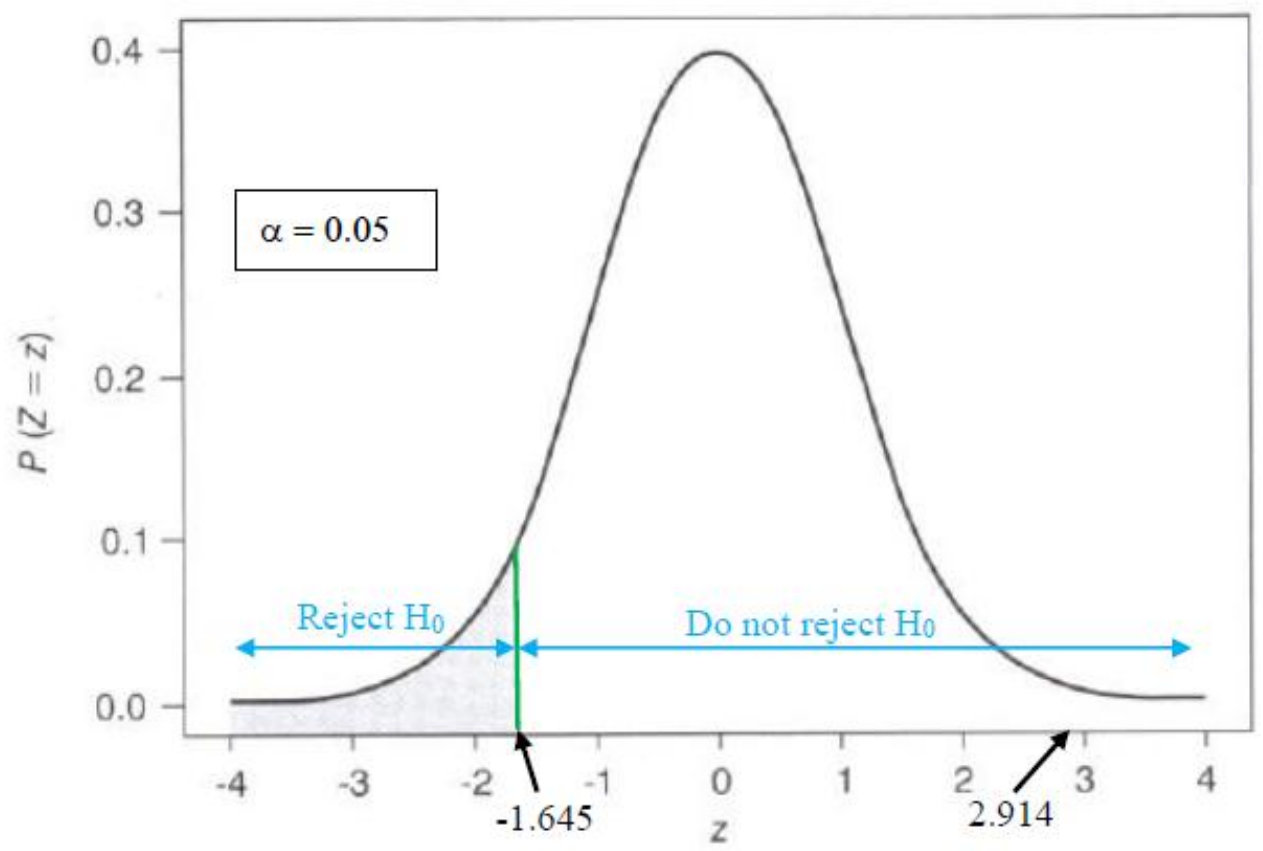

Figure 2. Z-value in Table 3 plotted into the distribution curve

By comparing the Z-value against the significance level of 5 percent, the value shall be more than -1.645 in order to reject the null hypothesis. As shown in Table3, the Z-value computed is 2.914 , and in Figure 2, the value is at the left-hand side of the bell curve. Thus, the null hypothesis is accepted at the 5 percent level of significance.

From both the findings on differences of share prices, either in amount or in percentage, they are consistent as both also have sufficient evidence exists to support the null hypothesis. The result indicates that dividend omission will not create a negative impact on share prices of the companies. 


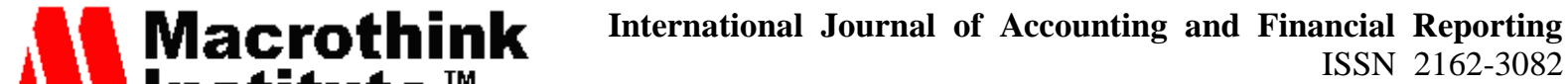 2018, Vol. 8, No. 2}

Table 4. Companies and frequency of dividend initiation

\begin{tabular}{|c|c|c|c|c|c|}
\hline No. & Company & $\begin{array}{c}\text { Frequency } \\
\text { of Dividend } \\
\text { Initiation }\end{array}$ & No. & Company & $\begin{array}{c}\text { Frequency } \\
\text { of Dividend } \\
\text { Initiation }\end{array}$ \\
\hline 1 & Asia Pacific Breweries Limited & 10 & 26 & Keppel Land Limited & 6 \\
\hline 2 & Bukit Sembawang Estates Limited & 9 & 27 & Kim Eng Holdings Limited & 6 \\
\hline 3 & Captial Land Limited & 5 & 28 & MCL Land Limited & 5 \\
\hline 4 & Cerebos Pacific Limited & 5 & 29 & Metro Holdings Limited & 6 \\
\hline 5 & City Developments Limited & 6 & 30 & Midas Holdings Limited & 19 \\
\hline 6 & ComfortDelGro Corporation Limited & 10 & 31 & Neptune Oriental Lines Limited & 9 \\
\hline 7 & Cosco Corporation (S) Limited & 5 & 32 & Noble Group & 5 \\
\hline 8 & Creative Technology Limited & 4 & 33 & Oversea Chinese Banking Corporation Limited & 11 \\
\hline 9 & CWT Limited & 6 & 34 & Parkway Holdings Limited & 16 \\
\hline 10 & DBS Group Holdings Limited & 20 & 35 & Raffles Education Corporation Limited & 17 \\
\hline 11 & Ezra Holdings Limited & 6 & 36 & Rotary Engineering Limited & 7 \\
\hline 12 & Fraser and Neave Limited & 10 & 37 & SembCrop Industries Limited & 5 \\
\hline 13 & Golden Agri Resources Limited & 5 & 38 & SembCrop Marine Limited & 10 \\
\hline 14 & Goodpack Limited & 5 & 39 & SIA Engineering Company Limited & 10 \\
\hline 15 & GP Batteries International Limited & 10 & 40 & Singapore Airlines Limited & 9 \\
\hline 16 & Great Eastern Holdings Limited & 10 & 41 & Singapore Airport Terminal Services Limited & 10 \\
\hline 17 & Guoco Land Limited & 5 & 42 & Singapore Exchange Limited & 20 \\
\hline 18 & Haw Par Corporation Limited & 10 & 43 & Singapore Post Limited & 20 \\
\hline 19 & Ho Bee Investment Limited & 9 & 44 & Singapore Press Holding Limited & 10 \\
\hline 20 & Hong Leong Asia Limited & 10 & 45 & Singapore Telecommunications Limited & 9 \\
\hline 21 & Hotel Properties Limited & 6 & 46 & SMRT Corporation Limited & 10 \\
\hline 22 & Hyflux Limited & 5 & 47 & Starhub Limited & 18 \\
\hline 23 & Isetan (Singapore) Limited & 6 & 48 & Swissco International Limited & 5 \\
\hline 24 & Jardine Cycle \& Carriage Limited & 11 & 49 & Wilmar International Limited & 5 \\
\hline 25 & Keppel Corporation Limited & 9 & 50 & Yeo Hiap Seng Limited & 1 \\
\hline
\end{tabular}

Source: www.sgx.com

From Table 4, the 50 companies that are randomly chosen from Singapore Stock Exchange are recorded and the frequency of the dividend initiation is monitored. The total number of dividend initiation done from the year 2009 to 2013 is 446 times. In order to find out the objective of second research hypothesis $\mathrm{H}_{20}$, the share prices fluctuation before and after the dividend initiation have examined. First of all, as conducted in a study done by McCluskey et al (2006), the share prices 20 days before and 20 days after the dividend initiation are plotted. The differences among the mean share prices before and after are compared. If there is an increment after the dividend announcement, then the hypothesis will prove the research question to be true. The hypothesis is to test the changes in the share price. The changes of the share price is $\mu$.Thus, the hypothesis can be interpreted as below: 


\section{1l Macrothink}

$\mathrm{H}_{0}: \mu \leq 0$

$\mathrm{H}_{\mathrm{A}}: \mu>0$

Where, $\mu=$ the differences between the share prices.

Table 5. Z-test result for share price differences (initiation)

\begin{tabular}{lc}
\hline Description & Figure \\
\hline Sample size & 446 \\
\hline Mean & 0.017446794 \\
\hline Standard Deviation & 0.464612256 \\
\hline Level of Significance & 0.05 \\
\hline Z-value & 0.793035071 \\
\hline
\end{tabular}

Source: Data Analysis

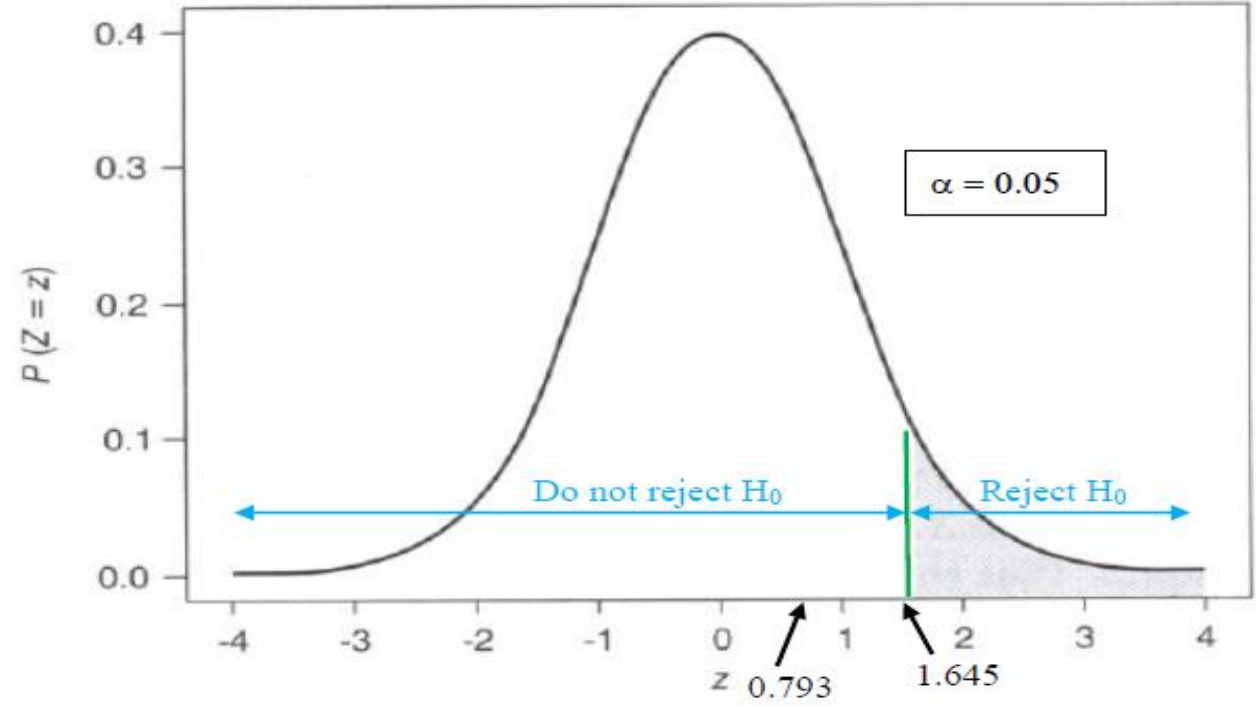

Figure 3. Rejection region for a one-tail test of a 'less than or equal' null hypothesis at the 5 percent level of significance

The Z-test conducted is an upper tail test. The significance level assumed for this test is 5 percent. If the Z-value obtained is more than 1.645 , then there will be sufficient evidence to reject the null hypothesis. However, the result calculated for $\mathrm{Z}$-value is 0.793 as per Table 5 . Therefore, the null hypothesis is accepted at 5 percent level of significance followed by the result plotted in Figure 3.To further investigate the hypothesis, the amounts of changes in the share prices are converted into a percentage. Then, the Z-value has calculated again and tested. The results are plotted in the below Table 6 . 


\section{Al Macrothink \\ International Journal of Accounting and Financial Reporting

Table 6. Z-test result for differences in percentage (initiation)

\begin{tabular}{lc}
\hline Description & Figure \\
\hline Sample size & 446 \\
\hline Mean & $0.830 \%$ \\
\hline Standard Deviation & 0.111423811 \\
\hline Level of Significance & 0.05 \\
\hline Z-value & 1.572799965 \\
\hline
\end{tabular}

Source: Data Analysis

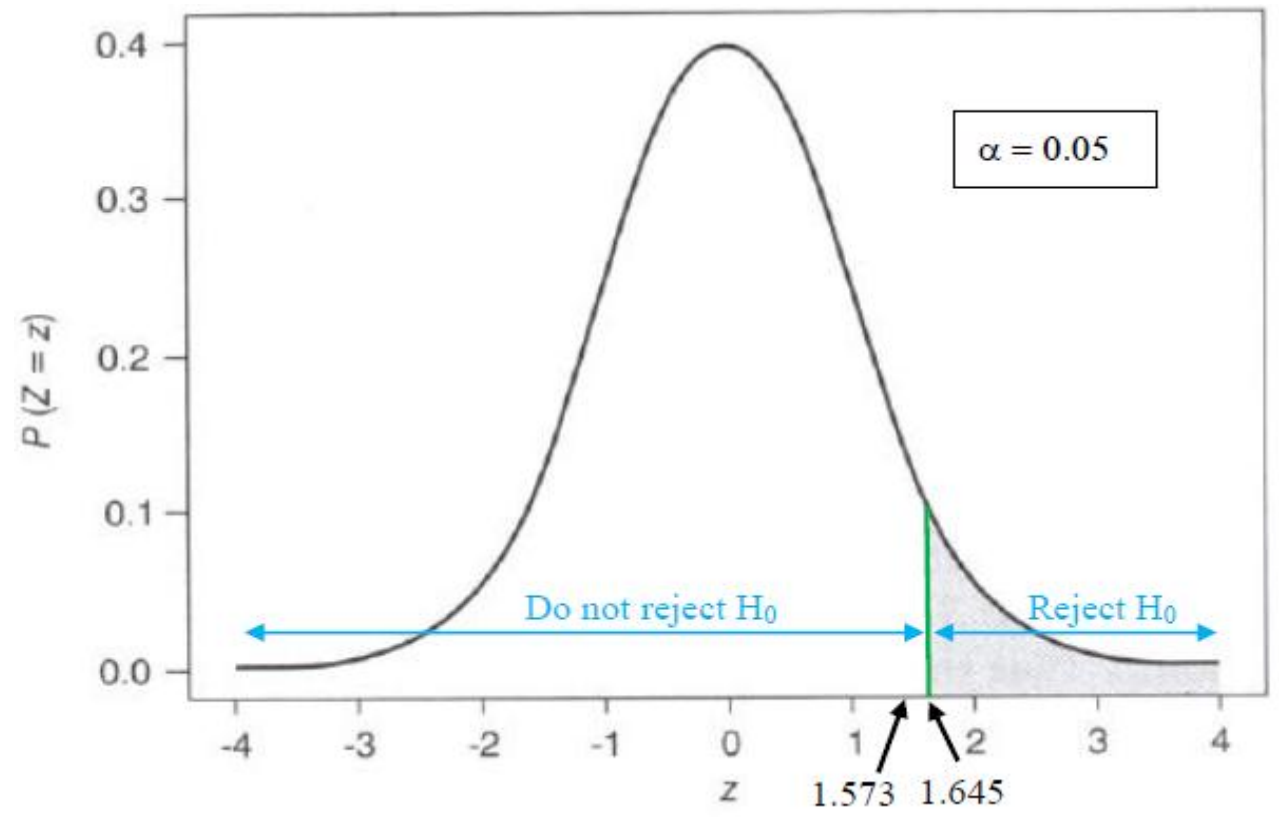

Figure 4. Z-value in Table 6 plotted in a distribution curve

By using the same method, the Z-value is compared against the level of significance of 5 percent, which is 1.645 . The Z-value of 1.573 is falling on the left-hand side of the 1.645 value, so the figure is smaller. Thus, the null hypothesis is accepted at 5 percent level of significance as shown in Figure 4.

From both the results obtained either tested on the differences of share prices in value or in percentage, the data computed is the same. So enough evidence exists to not to reject null hypothesis $\mathrm{H}_{20}$. This also concludes that dividend initiation will not create a positive impact on companies' share prices. This finding is consistent with the studies done by Asquith and Mullins (1983), Miller and Modigliani (1961) and Watts (1973).

For finding the dividend initiation announcement's impact on the size of the firm, the firms have been categorized into two groups. One group is "big" firms, while another group is "small" firms. For each group, the dividend initiation frequencies and dates are monitored and recorded. After that, the differences between the share prices are calculated as in the previous two research hypotheses. The results are tested and compared with Z-test. The method of gathering data, data tabulation and calculation is similar for both groups. This will 


\section{1) Macrothink}

International Journal of Accounting and Financial Reporting

ISSN 2162-3082

2018, Vol. 8, No. 2

ensure the consistency of the results during the comparison. The companies which are labeled as "big" and "small" are classified in Table 7 and Table 8 respectively. The frequencies of dividend initiation are also recorded.

Table 7. "Large" firms with the dividend initiation frequency

\begin{tabular}{|c|c|c|}
\hline No. & Company & $\begin{array}{c}\text { Frequency of Dividend } \\
\text { Initiation }\end{array}$ \\
\hline 1 & Great Eastern Holdings Limited & 10 \\
\hline 2 & Wilmar International Limited & 5 \\
\hline 3 & DBS Group Holdings Limited & 20 \\
\hline 4 & Oversea Chinese Banking Corporation Limited & 11 \\
\hline 5 & Singapore Telecommunications Limited & 9 \\
\hline 6 & Singapore Airlines Limited & 9 \\
\hline 7 & CapitaLand Limited & 5 \\
\hline 8 & City Developments Limited & 6 \\
\hline 9 & Golden Agri Resources Limited & 5 \\
\hline $\mathbf{1 0}$ & Keppel Corporation Limited & 9 \\
\hline 11 & Jardine Cycle \& Carriage Limited & 11 \\
\hline 12 & Fraser and Neave Limited & 10 \\
\hline 13 & GuocoLand Limited & 5 \\
\hline 14 & Keppel Land Limited & 6 \\
\hline & Hong Leong Asia Limited & 10 \\
\hline & SembCorp Industries Limited & 5 \\
\hline 17 & Noble Group & 5 \\
\hline 18 & ComfortDelGro Corporation Limited & 10 \\
\hline 19 & Neptune Oriental Lines Limited & 9 \\
\hline 20 & Parkway Holdings Limited & 16 \\
\hline 21 & Hotel Properties Limited & 6 \\
\hline 22 & Singapore Press Holdings Limited & 10 \\
\hline 23 & SembCorp Marine Limited & 10 \\
\hline & Haw Par Corporation Limited & 10 \\
\hline & Ho Bee Investment Limited & 9 \\
\hline
\end{tabular}

Source: www.sgx.com 


\section{Ml Macrothink \\ International Journal of Accounting and Financial Reporting \\ ISSN 2162-3082 \\ 2018, Vol. 8, No. 2}

Table 8. "Small" firms with the dividend initiation frequency

\begin{tabular}{|c|c|c|}
\hline No & Company & $\begin{array}{c}\text { Frequency of dividend } \\
\text { initiation }\end{array}$ \\
\hline 1. & Cosco Corporation (S) Limited & 5 \\
\hline 2. & Singapore Airport Terminal Services Limited & 10 \\
\hline 3. & SMRT Corporation Limited & 10 \\
\hline 4. & Bukit Sembawang Estates Limited & 9 \\
\hline 5. & Metro Holdings Limited & 6 \\
\hline 6. & SIA Engineering Company Limited & 10 \\
\hline 7. & Asia Pacific Breweries Limited & 10 \\
\hline 8. & Kim Eng Holdings Limited & 6 \\
\hline & Singapore Exchange Limited & 20 \\
\hline 10. & Ezra Holdings Limited & 6 \\
\hline 11. & MCL Land Limited & 5 \\
\hline 12. & CWT Limited & 6 \\
\hline 13. & Creative Technology Limited & 4 \\
\hline 14. & Raffles Education Corporation Limited & 17 \\
\hline 15. & Goodpack Limited & 5 \\
\hline 16. & Yeo Hiap Seng Limited & 1 \\
\hline 17. & Hyflux Limited & 5 \\
\hline 18. & Cerebos Pacific Limited & 5 \\
\hline 19. & GP Batteries International Limited & 10 \\
\hline 20. & Midas Holdings Limited & 19 \\
\hline 21. & Rotary Engineering Limited & 7 \\
\hline 22. & Singapore Post Limited & 20 \\
\hline 23. & Isetan (Singapore) Limited & 6 \\
\hline 24. & Swissco International Limited & 5 \\
\hline 25. & Starhub Limited & 18 \\
\hline
\end{tabular}

Source: www.sgx.com

From Table 7, there are a total of 221 times of dividend initiation made by big firms from the year 2009 to 2013. While from Table 8, which is for small firms, documented 225 times of dividend initiation are recorded for the same period as the big firms. In order to infer the implication of the dividend announcement either on a "small" companies or "big" companies, a two-tail Z-test is carried out for the determination. If the dividend initiation information will create an impact on the share prices of "big" companies, then the share prices will increase. In this case, the changes of the share prices, $\mu$, will not be 0 .

$\mathrm{H}_{0}: \mu=0$ 


\section{Al Macrothink}

International Journal of Accounting and Financial Reporting

ISSN 2162-3082 2018, Vol. 8, No. 2

$\mathrm{H}_{\mathrm{A}}: \mu \neq 0$

Where, $\mu=$ the differences between the share prices.

In the case of "big" companies, there should not be any impact caused by the dividend initiation announcement because the alternative hypothesis is testing on the impact of dividend initiation, which will only affect the share prices of "small" companies. Thus the null hypothesis, $\mathrm{H}_{30}$, will be accepted if the share prices of the "big" companies remained unchanged.

Table 9. Z-test result for share price differences of "large" companies

\begin{tabular}{lc}
\hline Description & Figure \\
\hline Sample size & 221 \\
\hline Mean & 0.048120452 \\
\hline Standard Deviation & 0.520937979 \\
\hline Level of Significance & 0.05 \\
\hline Z-value & 1.373219046 \\
\hline
\end{tabular}

Source: Data Analysis

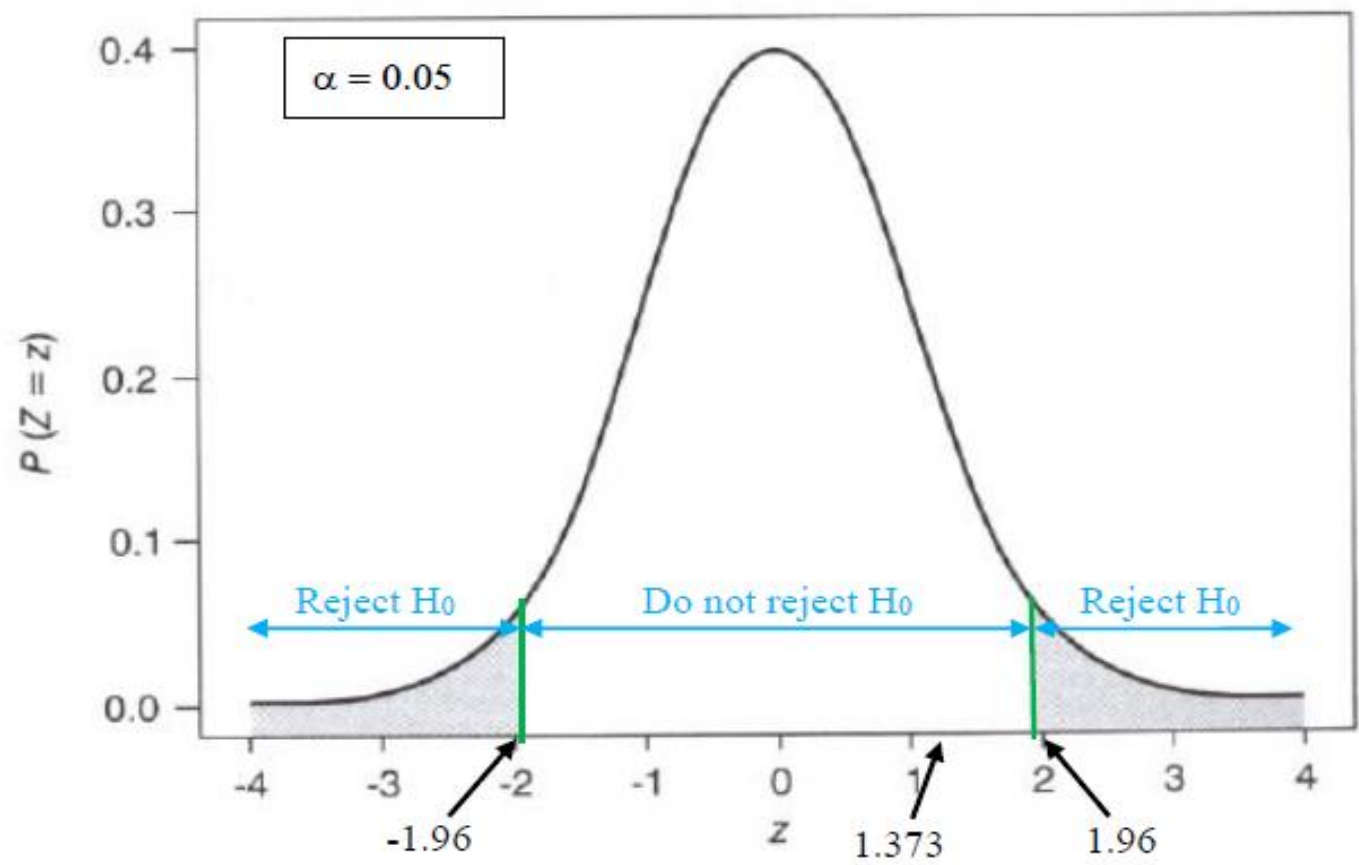

Figure 5. Z-value in Table 9 plotted in a distribution curve

The data from Table 9 is tabulated and shown in Figure 5. The Z-value of 1.373 is in the region where the null hypothesis cannot be rejected. Therefore, the null hypothesis is accepted at 5 percent level of significance. This also means that the share prices of the "big" companies are not affected by the dividend initiation announcement. Taking one step further, the differences in the share prices are converted into a percentage. The percentage should 


\section{Mll Macrothink}

International Journal of Accounting and Financial Reporting

ISSN 2162-3082

2018, Vol. 8, No. 2

remain $0 \%$ if there is no impact caused by the dividend initiation announcement. The results are tabulated in the Table10 below.

$\mathrm{H}_{0}: \mu=0$

$\mathrm{H}_{\mathrm{A}}: \mu \neq 0$

Where, $\mu=$ the differences between the share prices in percentage.

Table 10. Z-test result for share price differences in percentage of "big" companies

\begin{tabular}{lc}
\hline Description & Figure \\
\hline Sample size & 221 \\
\hline Mean & $1.343 \%$ \\
\hline Standard Deviation & 0.118523784 \\
\hline Level of Significance & 0.05 \\
\hline Z-value & 1.684128272 \\
\hline
\end{tabular}

Source: Data Analysis

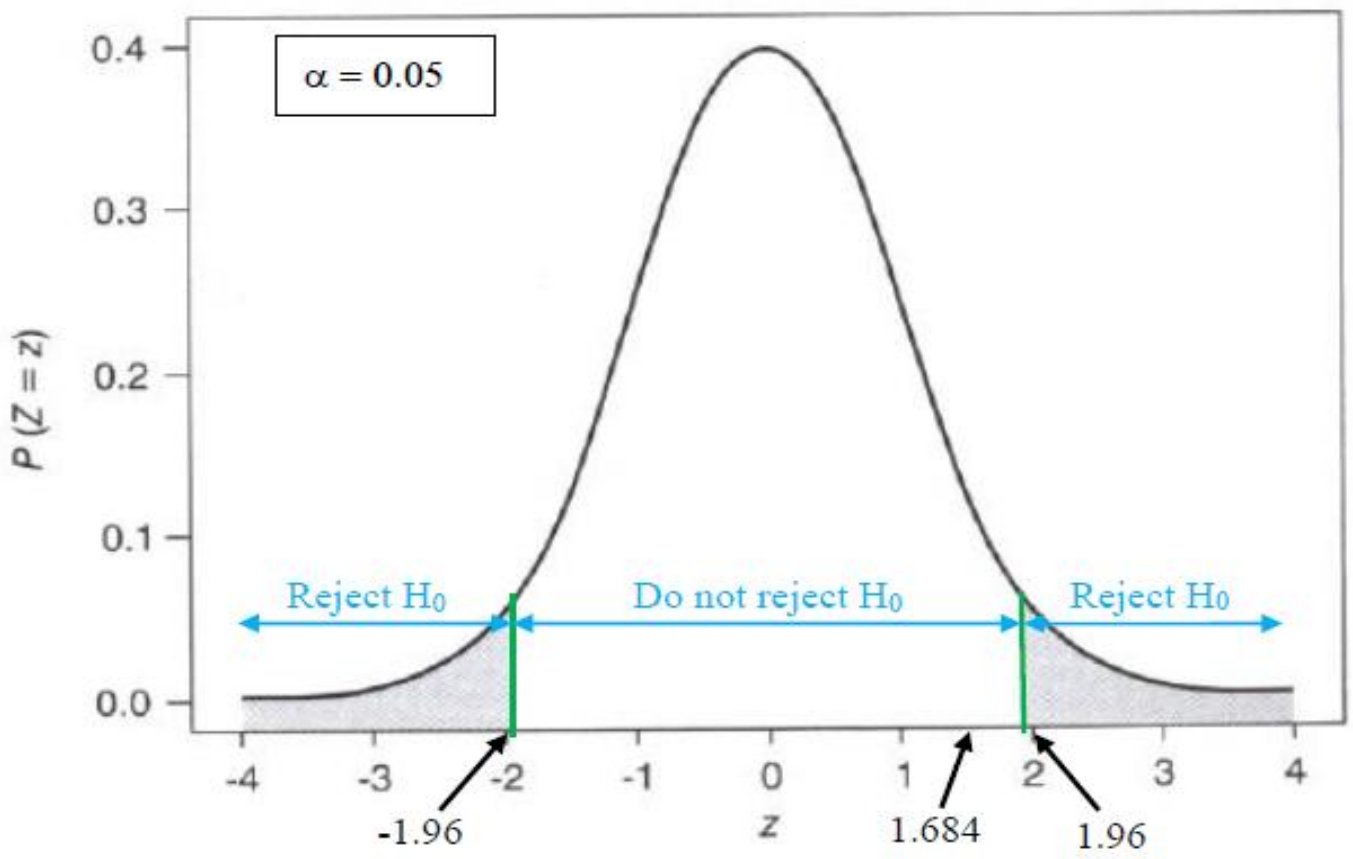

Figure 6. Z-value in Table 10 plotted in a distribution curve

The Z-value is lying in the region where the null hypothesis is accepted at 5 percent level of significance. This result is consistent with the finding where the differences in share prices are input in amount. At this step, the results only investigate the impact on "big" companies. For the analysis of "small" companies, the same method is adopted and analyzed. The differences of shares prices 20 days before and 20 days after the dividend initiation announcement is calculated and compared. If there is any impact, then the differences should not be 0 . From this logic, the below hypothesis is developed for testing. 


\section{1l Macrothink}

$\mathrm{H}_{0}: \mu=0$

$\mathrm{H}_{\mathrm{A}}: \mu \neq 0$

Where, $\mu=$ the differences between the share prices.

Table 11. Z-test result for share price differences of "small" companies

\begin{tabular}{lc}
\hline Description & Figure \\
\hline Sample size & 225 \\
\hline Mean & -0.012681556 \\
\hline Standard Deviation & 0.39938419 \\
\hline Level of Significance & 0.05 \\
\hline Z-value & -0.4762916 \\
\hline
\end{tabular}

Source: Data Analysis

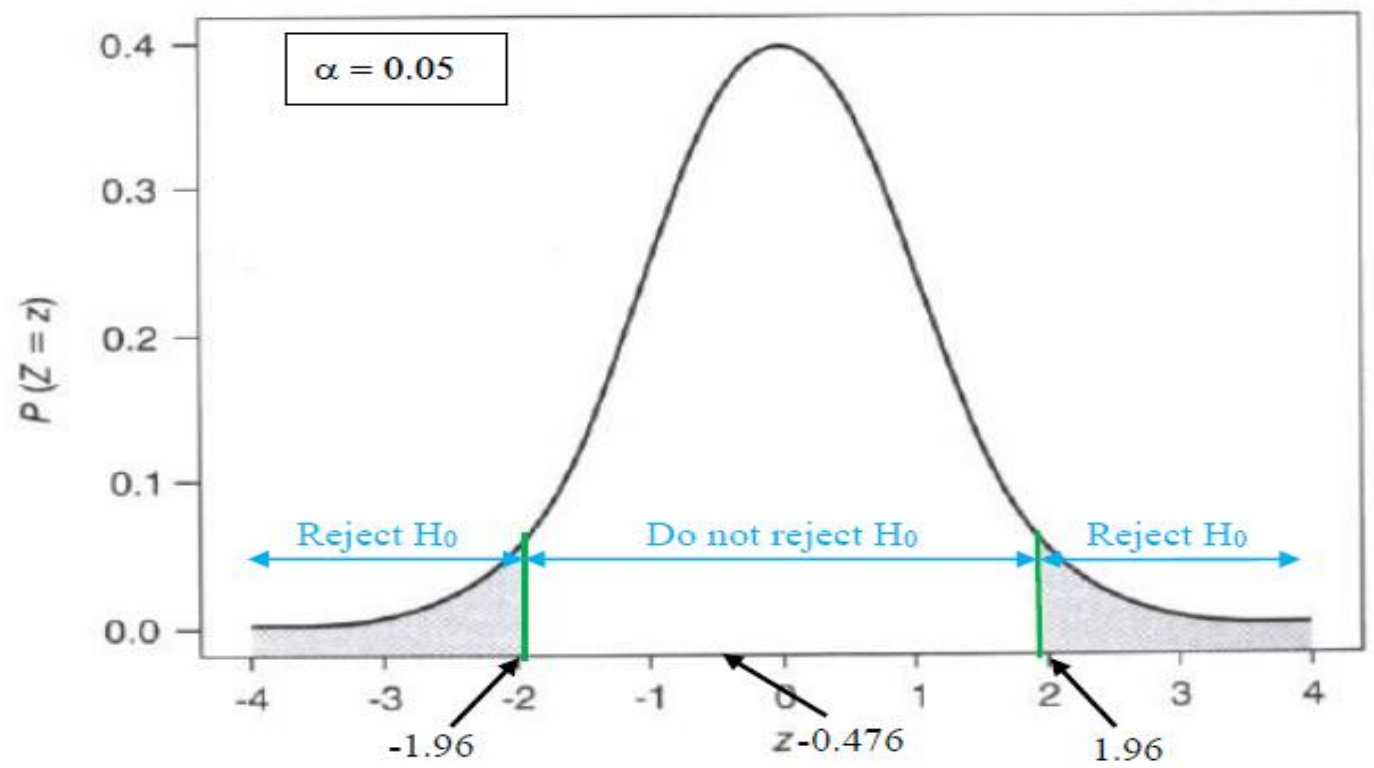

Figure 7. Z-value in Table 11 plotted in a distribution curve

As shown in Figure 7, the Z-value of the share price differences for "small" companies is within the region; therefore the null hypothesis $\mathrm{H}_{30}$ is accepted at 5 percent level of significance. This also implies that the share prices of the "small" companies will not be affected by dividend initiation announcement. Similar to what has been tested to "big" companies, by using the same set of data, but the differences in share prices are converted into a percentage. Then, Z-test is conducted on this percentage data.

$\mathrm{H}_{0}: \mu=0$

$\mathrm{H}_{\mathrm{A}}: \mu \neq 0$

Where, $\mu=$ the differences between the share prices in percentage. 


\section{Macrothink}

International Journal of Accounting and Financial Reporting

Table 12. Z-test result for share price differences in percentage of "small" companies

\begin{tabular}{lc}
\hline Description & Figure \\
\hline Sample size & 225 \\
\hline Mean & $0.326 \%$ \\
\hline Standard Deviation & 0.10373259 \\
\hline Level of Significance & 0.05 \\
\hline Z-value & 0.471464653 \\
\hline
\end{tabular}

Source: Data Analysis

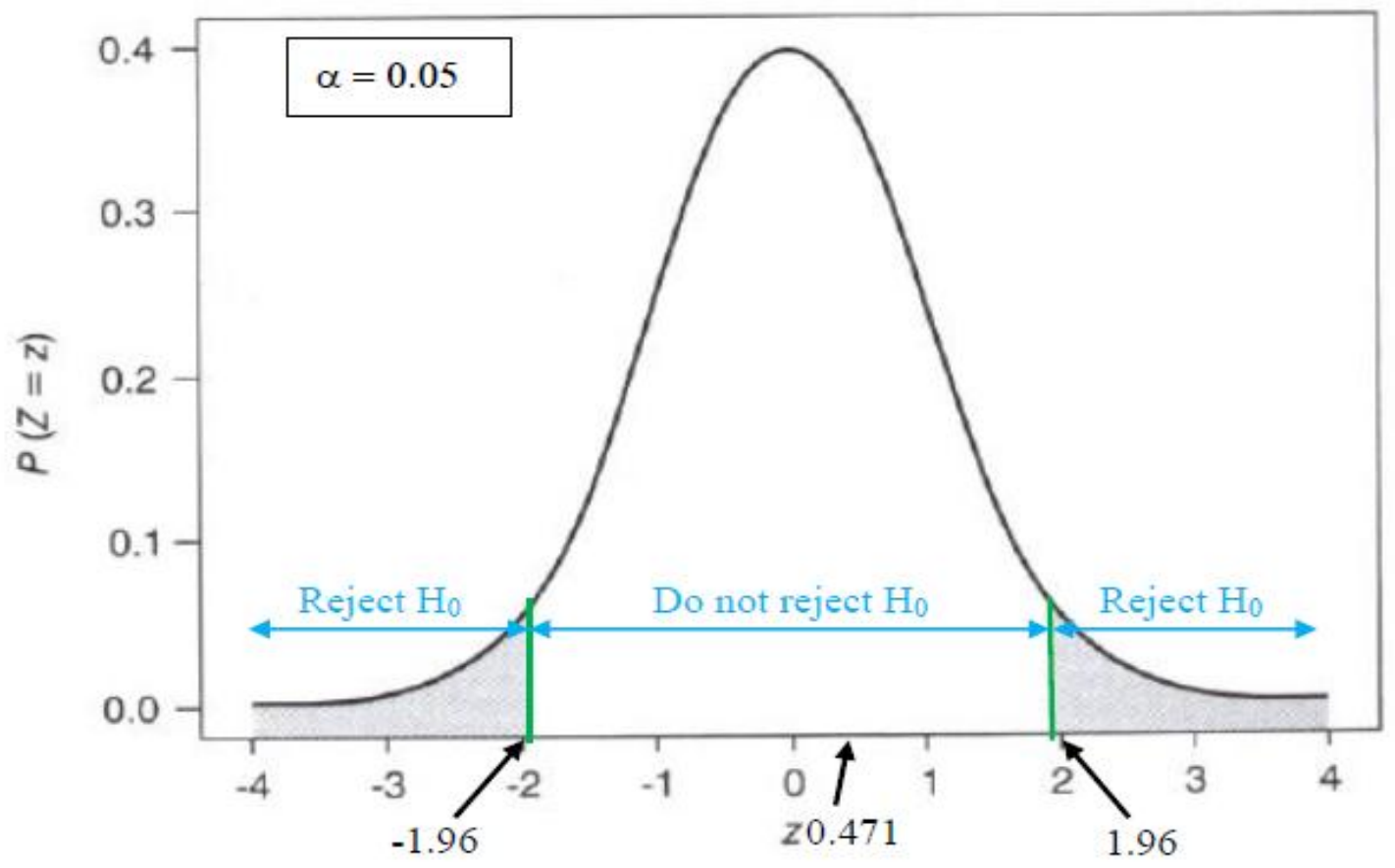

Figure 8. Z-value in Table 12 plotted in a distribution curve

The result for the "small" companies, either the differences of share prices in value or in percentage, they are located in the region where the null hypothesis $\mathrm{H}_{30}$ is accepted at 5 percent level of significance.

After comparing the differences of share prices between the "big" companies and "small" companies, against the dividend initiation announcement, it shows that there is no impact on either "big" or "small" companies. The null hypothesis $\mathrm{H}_{30}$ is accepted. This finding is consistent with L'Heureux (2000) where he also finds that the impact of dividend announcement will not be affected by the size of the firms.

For the testing of hypothesis four $\mathrm{H}_{40}$, the relationship between changes in dividend and a company's future earnings is examined. The changes of dividend and changes of future earnings are compared and analyzed. The data input is separated into two types: in value and in percentage. The test is also conducted for the overall relation, which tests for the relation from the year 2009 to 2013 apart from compared annually. 


\section{MInstitute ${ }^{\text {Mink }}$}

International Journal of Accounting and Financial Reporting

ISSN 2162-3082

In Table 13, the results shown are for the relationship between the dividend changes and companies' future earnings from the year 2009 to 2013.

Table 13. The changes of dividends and NPAT from 2009 to 2013

\begin{tabular}{lll}
\hline Year & Dividends changes & NPAT changes \\
\hline 2009 to 2010 & -0.162482208 & 0.37799681 \\
\hline 2010 to 2011 & -0.04522657 & 0.336875995 \\
\hline 2011 to 2012 & -0.188922816 & -0.083354324 \\
\hline 2012 to 2013 & -0.303880731 & -0.090890717 \\
\hline
\end{tabular}

Source: Data Analysis

The changes of the dividend are calculated by using the following formula:

$\Delta \operatorname{Div}=\left[\operatorname{Div}_{\mathrm{n}}-\operatorname{Div}_{\mathrm{n}-1}\right] / \operatorname{Div}_{\mathrm{n}-1}$

Where, $\operatorname{Div}_{\mathrm{n}}=$ Dividend in year $\mathrm{n}$

$\operatorname{Div}_{\mathrm{n}-1}=$ Dividend in year $\mathrm{n}-1$

$\Delta \mathrm{Div}=$ Changes of dividend

The value of Div is taking the sum of the dividend of the 50 companies chosen from Singapore Stock Exchange randomly throughout the year $\mathrm{n}$.

The changes of the net profit after tax (NPAT) are calculated by using the following formula:

$\Delta \mathrm{NPAT}=\left[\mathrm{NPAT}_{\mathrm{n}}-\mathrm{NPAT}_{\mathrm{n}-1}\right] / \mathrm{NPAT}_{\mathrm{n}-1}$

Where, $\operatorname{NPAT}_{\mathrm{n}}=$ Dividend in year $\mathrm{n}$

$\operatorname{NPAT}_{\mathrm{n}-1}=$ Dividend in year $\mathrm{n}-1$

$\triangle \mathrm{NPAT}=$ Changes of dividend

The value of NPAT is the sum of NPAT of the 50 companies which are randomly chosen from Singapore Stock Exchange annually.

Thereafter, by comparing the data as in Table 13, the correlation coefficient obtained is 0.749 . This figure is very close to +1 . Thus, there is a strong positive correlation between changes of dividend and changes of companies' future earnings. The alternative hypothesis is accepted in this case.

Taking one step further, the changes of the dividends and changes of the future earnings are converted into a percentage, and tested by annual basis. This set of data is also screened through to eliminate those outliers that may affect the accuracy of the results. 


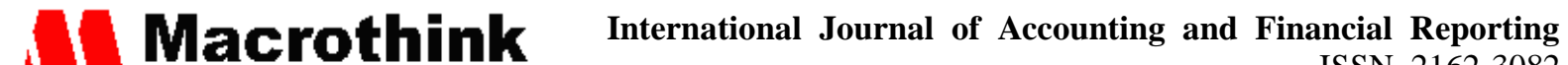 ISSN 2162-3082 2018, Vol. 8, No. 2}

Table 14. The correlation coefficient by comparing the data annually

\begin{tabular}{ll}
\hline Year & Correlation Coefficient \\
\hline 2009 to 2010 & 0.159095291 \\
\hline 2010 to 2011 & 0.013895646 \\
\hline 2011 to 2012 & 0.164855399 \\
\hline 2012 to 2013 & 0.067225269 \\
\hline
\end{tabular}

Source: Data Analysis

The results are plotted in Table 14. From these results, the correlation coefficient is a very small number compared to 1 . Thus, the relationship between dividend changes and future earning changes is very weak. In this case, the null hypothesis $\mathrm{H}_{40}$ is accepted.

There are two different outcomes from the tests that were conducted for this research hypothesis. When the data is considered by overall, which is looking at the dividend changes throughout the year 2009 to 2013 and future earnings changes throughout the same period, the year 2009 to 2013 , there is a strong and positive correlation between the two variables. However, when tested by annually with data input in percentage, the result shows otherwise, that there is very weak correlation between the two variables. This may be because the data input in the first case is by the sum of dividends payout annually by all the 50 companies, and the changes are then compared to the total NPAT of all the companies as well. Rather, in the second scenario, the correlation is calculated from the dividend changes of every company and NPAT of every company. The correlation between the dividend changes and future earning changes is trivial, and thus, null hypothesis $\mathrm{H}_{40}$ is accepted. This finding is consistent with the conclusion from Benartzi et al (1997) and DeAngelo et al (1995).

\section{Conclusion}

This research makes a number of contributions to the finance literature in general and to studies about the Singapore market in particular. In examining the efficiency of the Singapore stock market, the study looked at the speed of adjustment of share prices to the announcement of dividend payments and omissions for 50 companies which are randomly chosen from Singapore Stock Exchange. The first research hypothesis testing is about the impact of the dividend omission announcements on the share prices of the companies. The results indicated that there is no negative impact on the share prices after the dividend omission announcements. Normally most of the investors may be speculating that dividend omission is a reflection that the particular company has encountered financial difficulties, or even the company faces gloomy future prospects and thus the omission. It appears that the companies in Singapore do not have such negative impact from the dividend omission announcements.

The second research hypothesis is about the dividend initiation announcement, ie. whether it will create a positive impact on the companies' share prices. The empirical results show that the dividend initiation announcements will not create a positive impact on the companies' share prices. Since the test is done on Singapore market, it is very clear that the companies in Singapore will not be affected by the dividend initiation announcements. Indirectly, this 


\section{Mll Macrothink}

International Journal of Accounting and Financial Reporting

ISSN 2162-3082 2018, Vol. 8, No. 2

infers that most of the investors here will not perceive the initiation news as positive information.

From the first two research hypotheses, the empirical findings indicated that the dividend initiation (omission) announcements will not create positive (negative) impact on companies' share prices. This may be because managers and investors in Singapore perceive that there is no information being conveyed in the announcements. Dividend payout will not affect the company's share price or value.

Next, finding of research hypothesis three reflects that dividend initiation announcements will create no positive impact either on "big" or "small" companies. This finding supports the findings from the first two research hypotheses. Generally, the share prices of the companies in Singapore are not affected by the dividend announcements, be it omission announcements, or initiation announcements.

The last research hypothesis examines the relationship between the dividend payout changes and companies' future earnings changes. Findings draw two different conclusions. First, when the changes of the dividend payout are totaled up annually from all the companies, this is the first set of input. Then, the second set of input is calculated from the sum of the total annual net profit after tax (NPAT) of all the companies from 2009 to 2013. Next, these two sets of data are compared against each other. The correlation coefficient shows a strong positive relationship between these two sets of inputs.

Taking a step further, the dividend payout changes and net profit after tax changes are compared annually from the year 2009 to 2013. These sets of calculation show that there is a very weak relationship between the two variables since the correlation coefficient is very small. This reveals that by examining the overall relation, there is somehow a relationship exist between the dividend changes and NPAT changes. However, when focused on the relationship between the dividend changes and NPAT changes in a year, the relationship is very weak. Therefore, this reflects that the relationship between the dividend changes and NPAT changes is trivial and uncertain.

\section{References}

Asquith, P., \& Mullins, D. (1983). The Impact of Initiating Dividend Payments on Shareholders' Wealth. The Journal of Business, 56(1), 77-96. https://doi.org/10.1086/296187

Baker, H.K., Farrelly, G.E., \& Edelman, R.B. (1985). A survey of management views on dividend policy. Financial Management, 14(3), 78-84. https://doi.org/10.2307/3665062

Baker, H.K., \& Powell, G.E. (1999). How corporate managers view dividend policy. Quarterly Journal of Business and Economics, 38(2), 17-35.

Benartzi, S. Michaely, R., \& Thaler, R. (1997). Do Changes in Dividends Signal the Future or the Past? The Journal of Finance, 52(3), 1007-1034. https://doi.org/10.1111/j.1540-6261.1997.tb02723.x 


\section{$\triangle$ Macrothink}

International Journal of Accounting and Financial Reporting ISSN 2162-3082

Bhattacharya, S. (1979). Imperfect information, dividend policy, and the bird-in-the-hand fallacy. Bell Journal of Economics, 10(1), 259-270. https://doi.org/10.2307/3003330

Bhattacharya, S. (1980). Nondissipative Signaling Structures and Dividend Policy. The Quarterly Journal of Economics, 95, 1-24. https://doi.org/10.2307/1885346

Black, F. (1976). The dividend puzzle. Journal of Portfolio Management, 2(1), 1-22. https://doi.org/10.3905/jpm.1976.408558

Black, F., \& Scholes, M. (1974). The effects of dividend yield and dividend policy on common stock prices and returns. Journal of Financial Economics, 1(1), 1-22. https://doi.org/10.1016/0304-405X(74)90006-3

Brav, A., Graham, J.R., Harvey, C.R., \& Michaely, R. (2005). Payout policy in the 21st $\begin{array}{llll}\text { century. Journal of Financial } & \text { Economics, } & \text { 77(3), }\end{array}$ https://doi.org/10.1016/j.jfineco.2004.07.004

Buglear, J. (2008). STATS Means Business: A Guide to Business Statistics. Oxford: Butterworth-Heinemann.

DeAngelo, H., DeAngelo, L., \& Skinner, D. (1995). Reversal of Fortune Dividend Signaling and the Disappearance of Sustained Earnings Growth. Journal of Financial Economics, 40, 341-371. https://doi.org/10.1016/0304-405X(95)00850-E

Denis, D. Denis, D., \& Sarin, A. (1994). The Information Content of Dividend Changes: Cash Flow Signaling, Overinvestment and Dividend Clienteles. Journal of Financial and Quantitative Analysis, 29(4), 567-587. https://doi.org/10.2307/2331110

Dhanani, A. (2005). Corporate dividend policy: The Views of British Financial Managers. Journal of Business Finance and Accounting, 32(7/8), 1625-72. https://doi.org/10.1111/j.0306-686X.2005.00643.x

Gurgul, H. Majdosz, P., \& Mestel, R. (2006). Implications of Dividend Announcements for Stock Prices and Trading Volume of DAX Companies. Czech Journal of Economics and Finance, 56, 58-68.

Healy, P., \& Palepu, K. (1987). Earnings Information Conveyed by Dividend Initiations and $\begin{array}{llll}\text { Omissions. Journal of Financial Economics, 21, 149-175. } & \text {. }\end{array}$ https://doi.org/10.1016/0304-405X(88)90059-1

Ibrahim, A. (2002). A Re-examination of the Market's Reaction to Quarterly Dividend Change Announcements. Ph. D. University of Illinois.

Kaleem, A., \& Salahuddin, C. (2006). Impact of Dividend Announcement on Common Stock Prices at Lahore Stock Exchange (Pakistan). South Asian Journal of Management, 13(2).

Knight, R. (1991). The Information Content of Swiss Corporate Earnings and Dividend Announcements. Swiss Journal of Economics and Statistics, 127(3), 537-561. 


\section{Mll Macrothink}

International Journal of Accounting and Financial Reporting

ISSN 2162-3082 2018, Vol. 8, No. 2

L'Heureux, J. (2000). Canadian Market Reaction to Dividend Omission and Resumption Announcements. M. Sc. Concordia University.

Lang, L., \& Litzenberger, R. (1988). Dividend Announcements: Cash Flow Signalling vs. Free Cash Flow Hypothesis? Journal of Financial Economics, 24, 181-191. https://doi.org/10.1016/0304-405X(89)90077-9

Lonie, A.A., Abeyratna, G., Power, D.M., \& Sinclair, C.D. (1996). The stock market reaction to dividend announcements: a study of complex market signals. Journal of Economic Studies, 23(1), 32-52. https://doi.org/10.1108/01443589610106534

McCluskey, T. Burton, B. Power, D., \& Sinclair, C. (2006). Evidence on the Irish Stock Market's Reaction to Dividend Announcements. Applied Financial Economics, 16, 617-628. https://doi.org/10.1080/09603100600639058

McCluskey, T., Burton, B.M., \& Power, D.M. (2007). Evidence on the Irish financial directors' views about the dividend. Qualitative Research in Accounting \& Management, 4(2), 115-132. https://doi.org/10.1108/11766090710754196

Michaely, R. Thaler, R., \& Womack, K. (1994). Price Reactions to Dividend Initiations and Omissions: Overreaction or Drift? Journal of Finance, 50, 573-607. https://doi.org/10.1111/j.1540-6261.1995.tb04796.x

Miller, M., \& Modigliani, F. (1961). Dividend Policy, Growth, and the Valuation of Shares. The Journal of Business, 34(4), 411-433. https://doi.org/10.1086/294442

Miller, M.H., \& Scholes, M.S. (1982). Dividends and taxes: some empirical evidence. Journal of Political Economy, 90(6), 1118-41. https://doi.org/10.1086/261114

Penman, S. (1983). The Predictive Content of Earnings Forecasts and Dividends. The Journal of Finance, 38(4), 1181-1199. https://doi.org/10.1111/j.1540-6261.1983.tb02290.x

Pettit, R. (1972). Dividend Announcements, Security Performance, and Capital Market Efficiency. Journal of Finance, $42, \quad 489-911$. https://doi.org/10.1111/j.1540-6261.1972.tb03018.x

Singapore Exchange. (2010). Company All-in-One Info. Retrieved 10 June 2010, from http://www.sgx.com

Sun, A. (2005). The Informativeness of Dividend Announcements and the Market's Inefficient Response to Earnings. Ph. D. Carnegie Mellon University.

Uddin, M. H. (2003). Effect of Dividend Announcement on Shareholders' Value: Evidence from Dhaka Stock Exchange. Global Corporate Governance Forum (Sponsored by World Bank), 13-16 December, Hyderabad, (INDIA).

Watts, R. (1973). The Information Content of Dividends. The Journal of Business, 46(2), 191-211. https://doi.org/10.1086/295525 


\section{Macrothink \\ International Journal of Accounting and Financial Reporting ISSN 2162-3082 2018, Vol. 8, No. 2}

Walsh, L. (2001). The Impact of Dividend Initiations on Information Environment, Liquidity and Firm Value. Ph. D. The Pennsylvania State University.

Wong, N. (1985). A Study of Dividend Policies and Behaviors of Major Hong Kong Companies. MBA. The University of Hong Kong.

Yan, N. (2000). The Information Content of Dividends and the Market's Differential Reaction. Ph. D. University of Houston.

\section{Copyright Disclaimer}

Copyright for this article is retained by the author(s), with first publication rights granted to the journal.

This is an open-access article distributed under the terms and conditions of the Creative Commons Attribution license (http://creativecommons.org/licenses/by/4.0/) 